\title{
Performing to secure cultural hegemony: mediators' impact on the integration process
}

\author{
Agneta Moulettes \\ Strategic Communication, Lund University, Lund, Sweden
}

\begin{abstract}
Purpose - The article takes its point of departure in the current labor market debate on immigration policy and attempts to explore the way private labor market mediators involved in the integration of immigrants contribute to reproducing cultural stereotypes reminiscent of colonial ideas.

Design/methodology/approach - Findings are based on respondent-driven interviews with nine labor market mediators (seven women and three men) from eight private labor market agencies in Sweden.

Findings - The findings showed that the private labor market mediators put their trust in the neoliberal system and rely on the colonial discourses when convincing immigrants to assimilate into the dominant culture. At the same time, the findings also show that there is no evidence that the assimilating activities they offer will lead to long-term employment.

Research limitations/implications - Given that migration across national borders has become a common phenomenon, the author suggests a call for critical reflections on the taken-for-granted notions of both self and others and the influences colonial discourses have on integration.

Practical implications - The author would suggest a shift of focus from immigrants' cultural adjustment to society's and employers' responsibilities and readiness to adjust to prevailing conditions.

Originality/value - The study contributes to the labor market literature and the diversity management literature by adding insights from public labor market mediators' experiences of the help they offer immigrants to enter the labor market. It shows how mediators make use of dominating discourses to secure cultural hegemony.
\end{abstract}

Keywords Cultural hegemony, Postcolonial perspective, Private labor market mediators, Respondent-driven interviews, Unemployed immigrants

Paper type Research paper

\section{Introduction}

An expected shortage of labor in the European market due to a decreasing population poses a challenge for politicians, who have to negotiate between companies growing demand for skilled workers, on the one hand, and, on the other, a promise to the voters to limit immigration of nonEuropeans and the influx of refugees. The difficulty faced by immigrants in entering the labor market is a well-known problem among politicians and solving the issue has long been on the political agenda. What has made matters more complicated is the huge number of refugees that arrived in Europe due to recent conflicts in the Middle East and parts of the African continent. With a total number of 163,000 refugees, Sweden was one of the European countries that received the most refugees in 2015 (Migrationsverket, 2016). This in turn has made people more concerned about the economic strain that immigration constitute than the contributions that immigrants may offer to society in the long run. Besides a growing competition on the job market, immigrants' situation is further complicated by society's request for language skills and legitimate documentation of education and work experiences.

(C) Agneta Moulettes. Published by Emerald Publishing Limited. This article is published under the Creative Commons Attribution (CC BY 4.0) licence. Anyone may reproduce, distribute, translate and create derivative works of this article (for both commercial and non-commercial purposes), subject to full attribution to the original publication and authors. The full terms of this licence may be seen at http:// creativecommons.org/licences/by/4.0/legalcode

Received 31 July 2019 Revised 27 January 2020 2 September 2020

3 December 2020

Accepted 10 January 2021

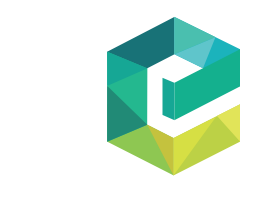

Equality, Diversity and Inclusion: An International Journal Vol. 40 No. 5, 2021 pp. $577-590$ Emerald Publishing Limited 2040-7149 DOI 10.1108/EDI-07-2019-0212 
EDI

40,5

Aiming at encouraging unemployed to take every opportunity to find a job, the Swedish government has modified the former government's slogan "working should be rewarded" to "it is your duty to take every chance for a job". Although who should be rewarded and what the term "a job" signify is open for interpretations, the political endeavor is to shorten the time it takes for immigrants to enter the labor market. Despite politicians' effort to make integration more efficient, current policy has encountered massive critique from all quarters of society including unemployed immigrants, who continue to experience discrimination and exclusion from the labor market. Compared to a $4 \%$ unemployment rate among the native Swedes, the number of unemployed immigrants amounted to more than $20 \%$ in 2017 (SCB, 2017).

Despite an apparently huge interest in integration issues and an extensive research devoted to immigrants' situation on the labor market, little scholarly attention has been directed toward private labor market mediators and the assistance they offer unemployed immigrants. Considering, however, that private labor market mediators have a strong position on the Swedish labor market, I argue that their role in the integration process deserve more scholarly attention. The overall aim of my paper is not simply to explore private mediators' involvement in the integration process but to explore how colonial discourses and ideas of self and others continue to influence the construction of everyday life. The article takes its point of departure in the current labor market debate on immigration policy and attempts to explore the way private mediators involved in the integration of immigrants contribute to reproducing cultural stereotypes reminiscent of colonial ideas. Before continuing, it needs to be pointed out that immigrants include newly arrived, first-, second- and third-generation immigrants as well as ethnic minority groups. The reason for this is that they are often treated as a homogenous group in the public debate as well as by labor market mediators.

\section{A brief overview of previous research}

Since the 1980s, when globalization rapidly increased and migration across nation borders became a common phenomenon, considerable scholarship has been devoted to issues related to immigrants' position in society. Today, studies on issues related to migration are so diverse that it is impossible to present a comprehensive and fair overview of the literature. Still, to positioning my study it seems reasonable to include a brief review.

A common characteristic in previous studies is the focus on ethnic discrimination and identifications of discriminatory factors (e.g. Colic-Peisker and Tilbury, 2007; Ponzoni et al., 2017). For instance, in his study on immigrants' situation in Sweden, Rydgren (2004) found that discrimination of immigrants, and especially non-Europeans, had been prevalent for decades, despite the government's efforts to protect them from unequal treatment and exploitation. Rydgren identified three mechanisms of exclusion as particularly important; statistical discrimination due to stereotypical thinking about ethnic groups, network effects due to the prioritizing of ethnical homogeneity and institutional discrimination due to the requirement of language skills or resettlement in municipalities where there is a shortage of jobs.

Although immigrants are more exposed to exclusion from the labor market, studies have shown that a great number of employers focus their recruitment policy on immigrant workers. One example is the study by Harisson and Lloyd (2013) on management attitudes which illustrates how employers actively seek to select workers who express subordination (e.g. who do not mind working long hours at lower wages), as it enables them to maintain power and privileges. According to Colic-Peisker and Tilbury (2007), this strategy is relevant also for high educated immigrants. In their study on migrants' integration into the Australian labor market they found that high educated immigrants often are offered jobs below their qualification. Besides ensuring employers power position the selection for subordination ensure the access to labor at the same time as it keeps labor costs down. This approach to 
immigrant workers is supported by governments' integration polices in many Western societies. For instance, in their analysis of the Nordic countries Calmfors and Sanchez Gasse (2019) suggest that the integration of immigrants, especially non-Europeans, could be improved by an increased wage inequality.

Still, other scholars have taken an interest in exploring immigrants' experiences of integration. The findings reveal, for instance, that most immigrants have experienced barriers that hampered their integration. The barriers included everything from discrimination due to ethnic background and language skills to homophilos networks and feelings of being exploited (e.g. Hakak et al., 2010). An exception to these findings is presented in the study by Ponzoni et al. (2017) on refugees in the Netherlands, which shows that they, in their eagerness to become integrated, accept discrimination as a normal feature in their everyday life.

However, building on a critical approach to neoliberalism Bernhardt (2015), argues that the welfare state neglect the influences of racial exclusion, while others, like Porter and Zhou (1993) warn that current policy may lead to segmented assimilation and, in the long turn, to permanent subordination. What I see as another shortcoming in previous studies is that they ignore the historical aspect and the impact of the colonial heritage on today's society and, thus, on the labor market. So far there are but a few studies that have explored the immigration policy and immigrants' position of the labor market from a postcolonial perspective (e.g. Krysa et al., 2017; Moulettes, 2015).

Although I am aware of the existence of success stories, this article will mainly focus on challenges that private mediators have experienced in their interactions with immigrants. With an overall aim to explore private mediators' role in the integration of immigrants on the labor market, I will draw on ideas from postcolonial theory, as I see it as potentially insightful lens for bringing cultural stereotypes reminiscent of the colonial discourse to the surface, and explore how these are currently employed. As critical management scholars (e.g. Prasad, 2012; Tuhiwai Smith, 2012; Jack and Westwood, 2009) remind us, postcolonial theory aims at highlighting that organizations maintain their embeddedness in Western rationalities characterized by national, cultural and racial hierarchies.

\section{Examining mediators' performances through the postcolonial lens}

Although the concept of coloniality and questions of colonialism and racism had been subjects of discussion in other parts of the world (Césaire, 2000; Fanon, 1967; Mariátegui, 1997; Memmi, 1991), it was Said (1995) that made Westerners aware of the way colonial ideas have influenced our perception of the world. What has made Said's groundbreaking book, Orientalism, survive for 40 years is most likely because he managed to capture the essence of the colonial strategy and delineate the consequences that still haunt us today. Hence, his work informs us that colonialism was one of the most profound and significant experiences that shaped Europeans' perception not only of Orientals but also, and perhaps mainly, of themselves as well as Orientals perceptions of themselves (Fougère and Moulettes, 2012). As argued by Said, the imperialist powers needed to create the Orient as an "Other," to define themselves as the center. To achieve success in this endeavor required a colonial strategy that systematically led colonizers to see themselves as superior and colonized people to see themselves as inferior.

Positioning culture as both resemblance and menace, Bhabha (1994) argues that "the colonial mimicry is the desire for a reformed, recognizable "Other", as a subject of a difference that is almost the same, but not quite" (p. 86). Simply put, mimicry refers to the fact that the colonized (the immigrant (my adding)) despite his attempt to imitate the colonizer (the host country (my adding)) will never really be recognized as the colonizers equal. Furthermore, culture is not an essentialistic phenomenon. Rather, it is a socially constructed phenomenon that needs to be continuously repeated to be kept alive. The construction of 
EDI

40,5

social labels is thus not just a way to make existence easier to comprehend but a way to fix people - a fixation that, in spite of an expressed desire among the colonialists to mold the others into a common pattern and the latter's effort to become integrated, will keep them apart. As Fanon (1967) suggested, this is a culture that is "fixed in its colonial status ... both present and mummified" (p. 44), and as such, it determines minorities' place in society.

A reason why the image of cultural homogeneity has become so important in today's society is probably people's enhanced effort to keep the discourse of cultural difference and the classification of people by race, ethnicity, geographic origin, gender, religion and the like, alive in times of increased migration and external pressure and uncertainty. Although professionals may be convinced that they treat everybody the same, it is plausible that their subjective notions and pressure from the environment to keep the image of cultural homogeneity alive, may affect their mindset and actions. The reproduction of cultural stereotypes and values that used to pass unnoticed needs now to be highlighted to secure the cultural hegemony. It is likely therefore that labor market mediators are conforming to the myth and values of their institutional environment (cf. Meyer and Rowen, 1977) as well as to governments' and employers' expectations of the immigrants.

\section{Colonial imprints and performativity}

Generally understood as talk and texts embedded in powerful institutions and practices critical discourse analysis (CDA) takes an interest in the exploration and delineation of power relations in society. In practice, this approach to discourse generally combines discourse analytic techniques with a critical perspective to interrogate social phenomena (Ainsworth and Hardy, 2004; Zanoni and Janssens, 2003). Referred to as "ideology critique" one of the versions of CDA targets the presumption, dissimulation or manipulation of knowledge that shapes people's mindset (Fairclough, 2003; Stenner and Marshall, 1995; Van Dijk, 1997). Scholars within this tradition argue that power relations in society are accompanied by a hegemonic language that systematically masks the world and claim that the aim of the critique is, therefore, to subvert power by showing the reality behind the ideology and what it really stands for (Winther Jørgensen and Phillips, 1999). This view is reminiscent of Gramsci's (1992) belief that ideologies have the power to reproduce social structures through institutions. It is, according to him, through social institutions such as churches and schools that ideas, beliefs, norms, values, expectations, behavior and worldviews are constructed, spread and maintained. The researcher's role is, thus, to unveil the ideology and what is hidden in the taken-for-granted assumptions so that people can get the chance to see and eventually challenge and change the prevailing discourses.

By and large, this view corresponds to Foucault's $(1963,1977)$ understanding of power as both productive and oppressive. Rather than forcing people to follow the rules, according to Foucault, applying impersonal surveillance that produces subjects who act as if they are being constantly watched and thus discipline their own behavior to achieve normality has become a successful means of control in modern society. A central function of institutions is, thus, for dominant groups (e.g. mediators) to socialize people (e.g. job seeking immigrants) into prevailing culture.

Instead of viewing culture as essentialistic, monolithic and static, I share the idea that they are talked into being and performed according to prevailing discourses. This broader view of language that was introduced by Austin (1962) and further elaborated by scholars like Derrida (1967) and Lyotard (1984), lay stress on the relationship between language and performativity. Even though their definition of performativity varies they share the view that we live in a performative culture where language is what constructs reality. Becoming aware of the obsession with the emphasis on performativity and effectiveness in the postmodern society Lyotard (1984) even feared that it at the very worst would exclude all those who do not 
comply with prevailing discourse at the workplace. Since then, the idea of performativity has been used by scholars who take an interest in the connection between structures, institutions and practice (Cameron, 1995; Lee, 2015).

\section{Performativity and colonial discourses}

The idea that performativity is about performing the normal within a discourse is, as pointed out by Cameron (1995), equally valid for any fixed and substantive social label. The continuous striving for normality is also the reason why the conception of cultural differences always needs to be repeated to be kept alive (Bhabha, 1994) - a repetition that appears to have become more intense due to globalization. Drawing on this insight, I argue that private mediators are socialized into prevailing discourses and influenced by mechanisms that impose efficiency (Lyotard, 1984) and normality (Foucault, 1977).

In this article, I rely on Said's (1995) notion of discourse as complex systems of colonial practices which varies in time and space. Hence, besides the discourse of difference, constructed on the binary between a superior us and an inferior them, there are manifold of discourses engrained in a colonial mindset operating in society and organizations. It makes it more relevant therefore to talk of colonial "discourses" rather than a colonial "discourse".

One of the discourses that since long has attracted a scholarly interest is the discrimination discourse. From having been focused on investigating blatant discrimination, a more recent interest in subtle discrimination of immigrants can now be discerned (Esses et al., 2006; Petersen and Dietz, 2005). In contrast to the former, which is easily recognizable through its belief in genetic inferiority and rejection of outgroups, subtle discrimination can be hard to discover and address since people cannot or will not admit to being prejudiced. According to Pettigrew and Meertens (1995) subtle discrimination involves the defense of traditional values, the exaggeration of cultural differences and denial of positive emotions. Examples of subtle discrimination occurs, for instance, in situations where immigrants are scapegoated, and when their skills are discouraged or devaluated as a pretext for exclusion.

Also, when perceived as a lack of qualification it is commonly referred to by diversity management scholars as a deficit (Zanoni and Janssens, 2003; Ponzoni et al., 2017). It is assumed, for instance, that immigrants cannot contribute as much as the indigenous population to the prosperity of the organizations while they lack proper education, language skills as well as cultural and social capital. To assimilate immigrants into the host culture, its proponents therefore suggest that training programs are implemented into the organizational strategy. From a postcolonial perspective, it could be argued that the deficit discourse is grounded on the perception of non-Westerners inferiority.

Finally, as diversity became a current feature in organizations strategy, scholars' interest in examining the ethnicity and cultural multiplicity increased. The findings of this research have shown a fragmented view of diversity where the proponents argue that diversity is "good for business", while the opponents are rather skeptical about the intentions behind the phenomenon (Bogaers et al., 2017; Zanoni and Janssens, 2003). Hence, studies have shown that the proponents argue that ethnic diversity favors companies' innovation capacities and thereby its profitability. Diversity has also proven to be appreciated among employers as immigrants are willing to take the jobs that indigenous population rejects.

However, the diversity concept has its opponents. For example, Lee (2015, p. 81) warned against liberal discourses of diversity, equality and tolerance arguing that it might "lull us into complacency that we have moved from the dark past". To Bhabha (1994) cultural diversity is nothing but an empirical knowledge used to categorize individuals in terms of fixed attributes to their respective cultures. It is a "camouflage" and an ironic compromise between a threat and a desirable object of Western possession. Previous studies have also pointed to its negative consequences, arguing for instance that ethnic minorities are valued 
by employers only because they, contrary to the ethnic majority, are compliant employees willing to accept discrimination and work conditions (e.g. Bogaers et al., 2017).

\section{Methodological considerations and research technique}

I present myself as a Swedish woman with no experiences of being a refuge or a non-European immigrant, but with a critical view on the way the world is discursively divided in one superior West and one inferior non-West, and who wish to destabilize the taken-for-granted assumptions embedded in mainstream perception on culture. The article is, thus, written from a Swedish perspective and draws on interviews with nine private mediators (seven women and two men) from eight private labor market agencies (see Table 1). Due to ethical reasons all participants have been anonymized. The interviewees were randomly chosen from a website with names of private mediators linked to the Swedish Public Employment Service (SPES).

\begin{tabular}{llll}
\hline Name & Gender & Educational background & Position \\
\hline Hanna & Female & Behavioral science & Coach \\
Emma & Female & Social work & Manager \\
Lisa & Female & Psychology & Manager \\
Adam & Male & Master of Pharmacology & Coach \\
Maria & Female & Social work & Coach \\
Katarina & Female & Behavioral science & Manager \\
Mats & Male & Behavioral science & Manager \\
Sandra & Female & Behavioral science & Coach \\
Nina & Female & PhD in Business & Self-employed \\
& & Administration & Coach \\
\hline
\end{tabular}

Table 1.

Background overview of interviewees
Since the research was exploratory in nature, I wanted the interviews to be respondentdriven rather than interview-driven. The interviews were performed, therefore, as conversations instead of conventional interviews based on semi-structural questionnaires (Kvale, 1996). This meant that I had prepared some questions that covered the main purpose of the research but kept the interviews as open as possible to allow participants to answer as freely as they wished. The choice of interview technique provided an opportunity for the participants to reflect on the areas they found to be most pertinent to the professional/client relationship. This meant that in some instances, questions were initiated by me, while in other instances, they were asked as natural follow-ups to the preceding conversation. But more importantly, it allowed unexpected reflections that might have remained silent in a semistructural interview.

The themes focused on mediators and their clients' background and experiences, the help they offer the immigrants to enter the labor market, the opportunities and hindrances they encounter, and their thoughts about the integration policy. The interviews lasted between 1 and $2 \frac{1}{2} \mathrm{~h}$ and were transcribed word for word. Since the interviews were conducted in Swedish, I only translated the parts of the transcripts that I thought could be useful for this text. To keep myself informed I collected various documents, e.g. Swedish Codes of Statutes, public authority reports, pamphlets, companies home pages, newspapers and took notes when I heard something on the TV news that I thought might be relevant.

In a first analysis of the transcripts I focused on finding instances when the participants discursively described their work encounters with immigrant clients. These primary findings were divided in preliminary themes based on their interaction with immigrants. In a second 
analysis I read the transcripts again but this time with an aim to trace accounts that could be stronger linked to mediators' work performances, and more precisely where they described how they helped immigrants to find a job. The most salient themes that appeared in the second analysis focused on (1) how colonial discourses came into use in mediators discursive accounts and (2) what impact this had on mediators' performances.

\section{Labor market assistance in Sweden}

The first step toward the creation of a public employment agency was taken in 1940 with the establishment of the Labor Market Commission. The aim was to help people earn their living during the Second World War. Over time, the commission's activities continually developed to reflect changes in the labor market and in society.

A significant change in the public mediators' work routines came in the early 1990s when new public management was implemented by the Swedish right-wing government. Inspired by neoliberal ideas and a wish to make the system more efficient, new routines, such as individual activation plans and work applications reports, were introduced. Another significant change came in 1993, when the employment agency's monopoly expired and the government opened for the establishment of private labor market agencies (SFS, 2014, p. 440 (Swedish Code of Statutes)). As a result, Sweden has witnessed a growing number of private businesses engaged in labor market services aiming at helping unemployed in finding jobs. The overall purpose was to broaden the services and ameliorate the matching of labor demand and supply. In 2007 the government mandated the SPES to delegate certain parts of their services to private actors. This meant that the private service provider agencies from now on are financially supported by the government to activate the unemployed clients they receive from SPES. Due to massive critique for being ineffective, the reform of SPES has continued and more work is supposed to be outsourced to independent actors in the future.

What characterizes the services offered by the private service providers is the acceptance of native-born Swedes, newly arrived refugees as well as immigrants who have lived in the country for various periods of time. All clients receive the same services, except for courses in Swedish core values and the Swedish language, which are only offered to immigrants. Most of them also offer support in various languages, e.g. English, Arabic, Persian, Dari and Spanish.

\section{Establishing cultural hegemony through the reproduction of colonial discourses The construction of others}

Through the analysis of mediators' discursive accounts, it turned out that there was an expectation of otherness underlying their descriptions of the help they offered to the unemployed immigrants. The mediators commonly made use of colonial discourses to describe the immigrants. For example, drawing on the superior/inferior binaries Nina explained that "There's a lot of ignorance amongst them... especially among immigrants who are unfamiliar with the system. Many of them do not know how to write a proper CV." Others, like Lisa, raised the question "who would hire someone who does not have a proper CV", while Hanna highlighted the importance of writing a personal letter marketing themselves as "Swedes". Making use of the national discourse and the image of Swedishness she concluded that:

You cannot start a letter by saying that you come from Syria. You must show that you have a certain competence. You must show that you do understand Swedish, that you understand what to do and that you know the codes. // It's important that you act as a real Swede, who knows the language and the codes. 
EDI

40,5

\section{4}

In their accounts, mediators emphasized the importance of informing immigrants what is expected of them and how they are supposed to behave to get a job. Because, as Emma explained "if you are to be integrated, it is important that you are included in society and that you become a full citizen". Mediators specifically reproduced the idea that Swedish language skills and cultural adjustments are keys to successful integration. This is evident also from Nina's conclusion that, "There are no jobs for those who cannot speak Swedish", and Sara claim that "It's always the language that is the hindrance". Furthermore, based on the assumption that immigrants lack the necessary sills for the Swedish labor market Emma explained that:

We offer them language courses two hours a week during a three month period, which includes many other exercises that. . that has to do with culture, organizational culture. . how to behave at the workplace and what you can and cannot do.

Obviously inspired by the colonial discourses and a desire to maintain cultural hegemony the mission was thus to convince immigrants of the importance not to reveal any unnecessary traces of cultural deviation from the normal, i.e. the Swedishness. Hanna, for instance, made use of the deficit discourse to legitimize her power as a professional mediator to make a Roma understand the importance to underline his Swedish identity.

He is a Roma, so they would never hire him if he had applied on his own. He would have sent his CV which says that he speaks Romani and would have been excluded immediately. You know that. I told him "You can remove it and say that Swedish is your maternal language". He had lived in Sweden all his life anyway.

Hanna's discursive account illustrates how structural racism against Roma is a taken for granted assumption that nobody even tries to hide. She based the argument on her interaction with the Roma to show how she, by urging him to remove his Roma background from the CV, helped him increase his chances of getting a job. At the same time as she reminded him of the fact that his Roma heritage was less valued on the Swedish labor market she contributed to the reproduction of prejudice against Roma. This construction of Roma as both included and excluded reminds of what Bhabha (1994) refers to as "recognizable others that are almost the same, but not quite".

However, even if the mediators perceived immigrants' lack of qualifications as a genuine problem, there was one who doubted that Swedish language skills were the real cause for excluding certain groups from being recruited. Adam, the only mediator with an immigrant background, claimed instead that the requirement was exaggerated:

There is no guarantee that Swedish language skills will end in a job. I have a woman from Pakistan. She came here six years ago and has a master's in chemistry from a Swedish university. She speaks four languages, Dari, English, Swedish and a local Pakistani language.

Adam's conclusion is consistent with earlier studies which showed that the request for qualification may conceal a form of subtle discrimination (Pettigrew and Meertens, 1995). Also, the fact that unemployment is significantly higher among immigrants compared to Swedes, and that this also applies to highly educated immigrants as well as those who have lived in Sweden for 20 years or longer (cf. SCB, 2017; Galte Schermer, 2019) indicate the involvement of subtle discrimination.

\section{Constructing the others into "bad" labor market actors}

The analysis of the interviews showed how mediators applied discourses of cultural otherness to make sense of situations they experienced as particularly challenging. The interview accounts illustrate how they attributed discriminating values to immigrants when they considered their behavior did not meet the expectations from the labor market. These situations proved to be most common when specific ethnic groups or nationalities were involved. 
For instance, Lisa employed colonial stereotypes to make sense of a situation where she failed to help a Middle East client finding a job.

I recall this man who had been in Sweden 15 years without a job. He had applied for more than 80 jobs. He was not motivated. My colleague used to say, "I cannot be in the same room as this person". He was so extremely negative. It didn't matter what we said. He infected the whole group. I took him aside and told him that I can't help you if you don't believe I can. In the end, we became so tired of him that we gave up.

Like her colleague, she seemed to have lost her patience with him because he "was not motivated", and on top of that was "so extremely negative". By employing derogatory language and her colleagues' consent, she constructed the "man" as a bad labor market actor whose negative attitude needed correction as it, besides "infecting the whole group", presumably also threatened her work performance. Instead of questioning if there might be other reasons why his 15 years in Sweden and his recent 80 job applications had not ended in employment, she jumped to the conclusion it was his reluctance to work that hold him back.

Another example is provided by Hanna, who once again used the Roma and the Somali to illustrate the difficulty to help someone who they believe does not wish to be helped to find a job.

Take this Roma guy for instance. His wife doesn't work, and they have three children. . . When I asked him what his friends do, he was embarrassed. If he is the first one to look for a job ... we know that there's a long tradition among these people. . . this group. If you say black Somalis, they have a hard time as well. I've had several that I've helped, but they must be committed because I can't get them to do something they don't want to do. I cannot do anything if they don't want me to.

Judging by Hanna's account, Roma and "black Somalis" are two ethnic groups who are particularly hard to help as they lack commitments. Interestingly, she mentions "black" Somalis as if she wants to make clear that there are "white" Somalis who do not encounter the same difficulty. Also, the fact that she mentioned that she asked the Roma client what his friends do and then implicitly suggesting he was embarrassed by the question, is intriguing as it unveils her own prejudice against Roma. While reproducing stereotypes about Roma as "traditionally" reluctant to work and "black Somalis" as a stubborn group of people, her statement discloses an essentialistic approach to culture that reproduces the discourse of difference and in particular the colonial binary of backward others (Said, 1995).

A similar example was forwarded by Lisa, who relied on her colleagues when claiming that there were those who have no intention of finding a job.

Lisa: I don't think there is anyone who has managed to get a Somali into work. . . ever. I don't know anyone.

I: But do you think it only depends on them?

Lisa: No, now I sound like a racist and that's awful. But if we talk about financial support. . . they have never had so much money in their whole life. They are very happy with the situation and find ways to survive.... They are used to living on nothing.

Lisa was quick to correct herself when she realized that her comment could be perceived as racist. Nevertheless, her belief that Somalis are "happy to live on financial support" and that they had "never had so much money" does not erase her prejudices. Her account implies that she may be affected by the zeitgeist and a collective generalization of certain ethnic groups (in this case the Somalis) that portrait them as inferior in comparison to the indigenous population. The fact that her allusion to financial support and economic poverty rather reinforces her prejudice against Somalis, shows the power with which colonial discourses and the perception of superior self and inferior others still affects our mindsets. 
EDI

40,5

\section{Performing the expected}

While the first sections to this part of the paper showed how colonial discourses are reproduced in mediators' discursive accounts, this section will focus on the impact they might have on mediators' performative discourse, and, hence, how they might influence mediators' role in the integration process.

As already mentioned earlier (cf. Galte Schermer, 2019) immigrants are more exposed to unemployment compared to Swedes and as a consequence often subjected to various short-time solutions like traineeship and temporary jobs. This in turn, may leave the mediators in a dilemma as they often have to persuade the unemployed immigrants to accept any activity they are offered. A common view that, for instance, Mats gave voice to was that "It's always better to have a job as a trainee even if it doesn't correspond to the education and what they want to do.... and eventually it may lead to a full-time employment".

Through the analysis of the discursive accounts, it turned out that references to the deficit discourse was a strategy they used to legitimize their persuasions. Hence, they commonly leant on the taken-for-granted assumption in today's debate that immigrants cannot contribute as much as the indigenous population to the organizations' effectiveness while they lack necessary qualification. Sara, who echoed Mats opinion about an eventual full-time employment explained how she recently persuaded an Iraqi woman to accept an internship although it was not consistent with her education and previous experiences.

I told her that "No, it's not a real job. You will not have the same responsibility as those who are paid... but your CV is empty and if you get some training at this hotel you will at least have something to put on your CV." So, from my point of view, it's not that negative.

Like Mats, Emma used career moves to justify a traineeship:

I think that the person who gets a job as a trainee will show that he can work and that he can be trusted... and is a resource. This person will not remain in that pay range for long. He will get another job and someone else will take his place.

The message the mediators communicated to the immigrants is apparently that they cannot be entrusted with a "real job" until they have shown they "can work" and "can be trusted". Then, when they have proven to be a "resource", they will be economically rewarded with full-time employment. Hence, by presenting their arguments on a vocabulary that expresses immigrants' subordination they convey the idea immigrants do not stand on equal footing with their Swedish competitors.

What further points in this direction is the role that the discounting of immigrants' education and earlier work experiences have for how the mediators guide immigrants to look for a job. Maria's story of how she helped the Iraqi woman is an example:

One of my clients was a woman from Iraq who had studied psychology and social work. Her husband had told her that she had to start all over as her education had no value in Sweden. I helped her to get a job in the day-care sector. But she was integrated and modern. She didn't have a veil and stuff. ...

Although the Iraqi woman did not get a job she was trained for, it was possible for Maria to help her as she was "integrated and modern" and as "she didn't have a veil and stuff". Hence, she represented the ideal immigrant employee - an educated, integrated and modern woman and a "good" labor market actor who complies to the expectations. The stress on modernity and the fact that she did not wear a veil mirrors the impact of a colonial mindset (Said, 1995) and the link between the fear of difference (Bhabha, 1994) and what it might mean for our supposed cultural identity. It reveals how the veil has come to symbolize Muslim women as oppressed and bound to traditions.

The Iraqi woman is probably the kind of "resource" that employers are seeking as they can be expected to do a "good" job for less money. Bearing earlier studies in mind which have 
shown that employers actively are selecting high educated workers who express subordinations (e.g. Colic-Peisker and Tilbury, 2007), I asked the mediators if employers might take advantage of immigrants. Hanna's immediate answer was:

Well, of course they are. Yes. . maybe not so much in terms of financial support, but they are good at utilizing trainees in a very, very ugly way. That is true of all industries, but I have to say that the municipalities are the worst. Because almost $50 \%$ of their staff are trainees.

Maria defended the system by explaining that:

It's an advantage for employers to hire trainees as they are cheap. There are businesses that operate entirely by engaging cheap labor. I don't think there's a risk of wage dumping. I rather think it is a way of helping people. It's cheaper and easier for employers.

What Hanna and Maria seem to suggest is that immigrants and the indigenous populations working conditions do not necessarily have to be the same. As private business owners or employers in a private company, it does not come as a surprise that they defend this strategy. It further indicates that their view is in accordance with the neoliberal idea to secure employers' power position by promoting the subordination of immigrants (cf. Harisson and Lloyed, 2013; Colic-Peisker and Tilbury, 2007).

The only mediator who expressed concern about an unfair treatment was Adam. Apart from poorer working conditions, he claimed that immigrants work applications often were overlooked in the recruitment process. "There's no way I can prove it. It is probably true also for age and perhaps even for gender", he said and continued:

But regarding age and ethnicity, you have to ask yourself. It happens quite often that they don't get a job that matches their academic education. The Iranian chemist who got a $\mathrm{PhD}$ from England. . . he has been in search of a job for ten years. He is 57 so we have started the difficult discussion about his future....//Identity is equally important. . . and he takes pride in his $\mathrm{PhD}$.

It is remarkable that the only interviewee, that emphasized structural differences of treatment, was the mediator with an immigrant background who shared similar experiences as the unemployed immigrants. Although this is just one case, it suggests that having this experience as an immigrant might make mediators more sensitive to patterns of structural exclusions of immigrants.

\section{Conclusions}

The overall aim of the study was to contribute to previous research on immigration by exploring public labor market mediators' role in the integration process. The fact that the interviews were respondent-driven, meant that mediators who took part in the study chose what they considered most relevant in the context of their interactions with unemployed immigrants. As a result, the conversation came to focus on the help they offered unemployed immigrants, the challenges they encountered in their interactions with their clients and what they assumed employers expected of them. The choice of method contributed thus to highlight what interviewees saw as most important in their interactions with immigrants and interestingly it did not include cultural diversity. The major contribution of the study is its attempt to analyze market mediators discursive accounts from a postcolonial perspective, and how colonial discourses influence the performances of labor market mediators.

The findings show that colonial discourses continue to influence the perception of others and especially of non-Western immigrants and minority ethnic groups. It further shows the impact that colonial discourses may have on mediators' performative discourse. It shows that mediators trust in the assumption that culture is an essentialistic phenomenon and that cultural stereotypes are (un)reflectively reproduced in their discursive accounts. The fact that non-Westerners and Roma was the only groups referred to in their stories indicates that 
EDI

40,5

588

they were considered to deviate the most from the norm and, hence, those most in need of assimilation in order to maintain cultural hegemony. However, there is nothing in the findings showing that preparatory activities or traineeship and short-time work will lead to long-time employment. These solutions seemed instead to be a way to keep the unemployed immigrants active and to serve employers with cheap labor. This strategy seems reasonable from the mediators' perspective as they are obliged to wait for full economic compensations until the client has been employed. Bearing in mind that mediators insist in persuading immigrants to accept a traineeship even when they know they will be badly treated, indicates that they put their trust in the neoliberal system and the perception of immigrants as "desirable objects" (Bhabha, 1994) who are content to comply to employers wishes even if it means hard work for lower wages than the native Swedes (cf. Harisson and Lloyd, 2013; Bogaers et al., 2017). The fact that immigrants are singled out and treated differently support Bhabha's (1994) claim that cultural diversity is nothing but an empirical knowledge used to categorize individuals in terms of fixed attributes to their respective culture. It seems as if immigrants' situation as unemployed too often and too simplistically is blamed on their lack of competences while the question how they are supposed to meet the competition from the indigenous populations rarely is a subject for discussions.

The conclusion I draw from my study is that integration is bound to failure as long as people of different nationalities, ethnicities, religion and ideologies must strip themselves of whatever have made them different and pretend to undertake an identity that fits the dominating discourses. It is my contention that real integration can only be achieved when we have accepted differences as a normal constituent in the diversity discourse. Since this is an unattainable goal, I suggest a call for critical reflections on the taken-for-granted notions of both self and others and the influences colonial discourses have on integration. An enhanced awareness of the prejudices included in the colonial discourses could lead to a more nuanced approach and increase the chances of achieving the goal.

However, my study has only caught a glimpse of private labor mediators' role in the integration process, and given that immigration has proven to be difficult to address, more studies are needed. Studies focusing on immigrants' experiences of the help they receive from the mediators could contribute to broaden our insights into their role in the integration process.

\section{References}

Ainsworth, S. and Hardy, C. (2004), "Critical discourse analysis and identity: why bother?", Critical Discourse Studies, Vol. 1 No. 2, pp. 225-259.

Austin, J.L. (1962), How to Do Things with Words, Oxford University Press, Oxford.

Bernhardt, N.S. (2015), "Racialized precarious employment and the inadequacies of the Canadian welfare state", Journal of Workplace Rights, SAGE Open April-June 2015, Vol. 5 No. 2, pp. 1-13, doi: 10.1177/2158244015575639.

Bhabha, H.K. (1994), The Location of Culture, Routledge, London.

Bogaers, S., Van Lear, K. and Zanoni, P. (2017), "The other ideal employee: employers' construction of compliant ethnic minority employees", Paper submitted to "Sub-theme 17: Diversity and Diversity Management: Beyond the Familiar into the Unexpected" of the 34th EGOS Colloquium, Tallinn, Estonia, available at: http://hdl.handle.net/1942/26647.

Calmfors and Gasse, S. (2019), Integrating Immigrants into the Nordic Labour Markets, Nordic Council of Ministers, Nordisk Ministerråd, Copenhagen.

Cameron, D. (1995), Verbal Hygiene, Routledge, New York, NY.

Césaire, A. (2000), Discourse on Colonialism, (original title Discours sur le Colonialism first published in 1950), Monthly Review Press, New York. 
Colic-Peisker, V. and Tilbury, F. (2007), "Integration into the Australian labour market: the experience of three 'visibly different' groups of recently arrived refugees", International Migration, Vol. 45 No. 1, pp. 59-85.

Derrida, J. (1967), De la grammatologie. (Grammatology), Les Editions de Minuit, Paris.

Esses, V.M., Dietz, J. and Bhardwaj, A. (2006), "The role of prejudice in the discounting of immigrant skills", in Mahalingam, R. (Ed.), Cultural Psychology of Immigrants, Lawrence Erlbaum, Mahwah, NJ, pp. 113-30.

Fairclough (2003), Discourse and Social Change, (first edited 19929), Polity press, Cambridge.

Fanon (1967), Peau Noire, Masque Blanc, Pluto Press, London, first published 1952.

Foucault, M. (1963), The Birth of the Clinic: An Archaeology of Medical Perception, Routledge, London.

Foucault, M. (1977), Discipline and Punish: The Birth of the Prison, Penguin, Harmondsworth.

Fougère, M. and Moulettes, A. (2012), “A postcolonial reading of Hofstede's culture's consequences”, in Prasad, A. (Ed.), Against the Grain: Advances in Postcolonial Organization Studies, Copenhagen Business School Press, Copenhagen, pp. 276-301.

Galte Schermer, I. (2019), “Arbetslöshet”, Ekonomifakta, available at: https://www.ekonomifakta.se/ Fakta/Arbetsmarknad/Arbetsloshet/Arbetsloshet/?gclid=Cj0KCQiAPjBRCWARIsADc18TIRg bg5kUhqlu_hZR0uq3Xd6BKVvKyU0zrwHjayqJuJ4EMM6iNaRdMaAu3nEALw_wcB.

Gramsci, A. (1992), Prison Notebooks. European Perspectives: A Series of Social Thoughts and Cultural Criticism, in Buttigieg, J., Vol. 1, Columbia University Press, New York.

Hakak, L.T., Holzinger, I. and Zikic, J. (2010), "Barriers and paths to success Latin American MBAs' views of employment in Canada", Journal of Managerial Psychology, Vol. 25 No. 2, pp. 159-176.

Harrison, J.L. and Lloyd, S.E. (2013), "New jobs, new workers and new inequalities: explaining employers' roles in occupational segregation by nativity and race", Social Problems, Vol. 60 No. 3, pp. 281-301.

Jack, G. and Westwood, R. (2009), International and Cross-Cultural Management Studies: A Postcolonial Reading, Palgrave Macmillan, New York, NY.

Krysa, I.M., Mills, A. and Barragan, S. (2017), "Canadian immigrants' guidelines on how to become productive members of society", Equality, Diversity and Inclusion: An International Journal, Vol. 36 No. 6, pp. 482-500.

Kvale, S. (1996), InterViews. An Introduction to Qualitative Research Interviewing, SAGE, Thousend Oaks CA.

Lee, E. (2015), "Doing culture, doing race: everyday discourses of 'culture' and 'cultural difference' in the English as a second language classroom", Journal of Multilingual and Multicultural Development, Vol. 36, pp. 80-93.

Lyotard, J. (1984), The Postmodern Condition: A Report on Knowledge, Manchester University Press, Manchester.

Mariátegui, J.C. (1997), Seven Interpretive Essays on Peruvian Reality (Siete Ensayos de Interpretación de la Realidad Peruana, or Los 7 Ensayos), University of Texas Press, first published (1928), Austin, Texas.

Memmi, A. (1991), The Colonizer and the Colonized, Bacon Press, Boston, first published (1965).

Meyer, J.W. and Rowan, B. (1977), "Institutionalized organizations: formal structure as myth and ceremony”, American Journal of Sociology, Vol. 83, pp. 340-363.

Migrationsverket (2016), “Årsredovisning 2015”, available at: https://www.migrationsverket.se/ download/18.2d998ffc151ac3871593f89/1485556210405/\%C3\%85rsredovisning \%202015.pdf.

Moulettes, A. (2015), "The darker side of integration policy: a study of public employment officers' discursive construction of female immigrants' employability", Journal of Workplace Rights, Sage Open, Vol. 5 No. 2, pp. 1-13.

Petersen, L. and Dietz, J. (2005), "Prejudice and enforcement of workforce homogeneity as explanations for employment discrimination", Journal of Applied Social Psychology, Vol. 35 No. 1, pp. 144-59. 
EDI 40,5

Pettigrew, T.F. and Meerten, R.W. (1995), "Subtle and blatant prejudice in western Europe", European Journal of Social Psychology, Vol. 25, pp. 57-75.

Ponzoni, E., Ghorashi, H. and van der Raad, S. (2017), "Caught between norm and difference: narratives on refugees' inclusion in organizations", Equality, Diversity and Inclusion: International Journal, Vol. 36 No. 3, pp. 222-237.

Portes, A. and Zhou, M. (1993), "The new second generation: segmented assimilation and its variants", The Annals of the American Academy of Political and Social Science, Sage, Thousand Oaks, Vol. 530 No. 1, pp. 74-96.

Prasad, A. (2012), Against the Grain: Advances in Postcolonial Organization Studies, Copenhagen Business School Press, Copenhagen.

Rydgren, J. (2004), "Mechanism of exclusion: ethnic discrimination in the Swedish labor market", Journal of Ethnic and Migration Studies, Vol. 30 No. 4, pp. 697-716.

Said, E. (1995), Orientalism, Western Conceptions of the Orient, Penguin, Londo.

SCB (2017), "Foreign born persons have poorer matching between their education and the labour market", Statistical news from Statistics Sweden 2017-06-02 9.30, available at: https://www.scb. se/en/finding-statistics/statistics-by-subject-area/living-conditions/living-conditions/ integration-analysis/pong/statistical-news/integration-matching-on-the-labour-market/.

SFS (2014), “(Svensk författningssamling). Lag 1993: 440; om privat arbetsförmedling”, available at: http://www.riksdagen.se/sv/Dokument-Lagar/Lagar/Svenskforfattningssamling/Lag-1993440om-privat-arbet_sfs-1993-440/ (accessed October 2014).

Stenner, P. and Marshall, H. (1995), “D\&S forum”, Discourse and Society, Vol. 6, pp. 568-570.

Tuhiwai Smith, L. (2012), Decolonizing Methodologies, Zed Books, London.

Van Dijk, T.A. (1997), Discourse Studies: A Multidisciplinary Introduction, SAGE, London.

Winther Jørgensen, M. and Phillips, L. (1999), Diskursanalys som Teori Och Metod. (Discourse Analysis in Theory and Method), Studentlitteratur, Lund.

Zanoni and Janssens (2003), "Deconstructing difference: the rhetoric of HR managers' diversity discourses", Organization Studies, Vol. 25 No. 1, pp. 55-74.

\section{Further reading}

Guo, S. (2009), "Difference, deficiency, and devaluation: tracing the roots of non/recognition of foreign credentials for immigrant professionals in Canada", The Canadian Journal for the Study of Adult Education, Vol. 22 No. 1, pp. 37-52.

Hofstede, G. (2001), Culture's Consequences: Comparing Values, Behaviours, Institutions and Organizations across Nations, 2nd ed., SAGE, London.

Jansson, B. and Kilsved, H. (2013), "Granskning av upphandling av Arbetsförmedlingen", Svenskt Näringsliv, available at: www.svensktnaringslive.se.

Joyce, P. (2018), "Rätt jobb åt utrikes födda akademiker En samhällsekonomisk beräkning av en fungerande jobbkedja”, available at: https://www.jusek.se/globalassets/rapport_ratt-jobbutrikes-fodda-slutversion.pdf.

Swedish Public Employment Service (2018), available at: https://www.arbetsformedlingen.se/ Forarbetsgivare.html, then go to: https://arbetsformedlingen.se/for-arbetssokande/extra-stod/ stod-a-o/rusta-och-matcha/sok-leverantor-inom-rusta-och-matcha/.

\section{Corresponding author}

Agneta Moulettes can be contacted at: agneta.moulettes@gmail.com

For instructions on how to order reprints of this article, please visit our website:

www.emeraldgrouppublishing.com/licensing/reprints.htm

Or contact us for further details: permissions@emeraldinsight.com 